\title{
The effect of acute and chronic administration of the $\beta$-agonist, cimaterol, on protein synthesis in ovine skin and muscle
}

\author{
BY J. E. NASH${ }^{1}$, H. J. G. ROCHA ${ }^{2}$, V. BUCHAN ${ }^{2}$, G. A. CALDER ${ }^{2}$, E. MILNE ${ }^{2}$, \\ J. F. QUIRKE ${ }^{3}$ AND G. E. LOBLEY ${ }^{2 *}$ \\ ${ }^{1}$ Department of Agriculture, University of Aberdeen, Aberdeen AB9 1UD, ${ }^{2}$ Rowett Research \\ Institute, Bucksburn, Aberdeen AB2 9SB, ${ }^{3}$ Boehringer Ingelheim Vetmedica GMBH, 6507 \\ Ingelheim, Germany
}

(Received 25 January 1993 - Revised 14 May 1993 - Accepted 21 June 1993)

\begin{abstract}
The action of intravenous infusion of the $\beta$-agonist cimaterol $(2.5 \mathrm{mg} / \mathrm{d})$ on whole-body $\mathrm{N}$ retention and protein synthesis in peripheral tissues was examined in growing sheep. Wool growth was determined from skin patch clippings and adjusted to total fibre production. Protein synthesis was measured, using sequential large dose injections of $\left[1-{ }^{13} \mathrm{C}\right]$ valine, leucine and phenylalanine and then $\left[\right.$ ring- $\left.\mathrm{d}_{5}\right]-$ phenylalanine, on biopsy samples from skin and $m$. longissimus dorsi taken before $\beta$-agonist administration, at day 3 and day 15 of cimaterol infusion, and $15 \mathrm{~d}$ after withdrawal of the drug. Cimaterol increased total $\mathrm{N}$ retention by $1.9-2.3 \mathrm{~g} \mathrm{~N} / \mathrm{d}(P<0.01)$ over three successive $5 \mathrm{~d}$ periods. In contrast, wool growth was significantly reduced by $0.7 \mathrm{~g} \mathrm{~N} / \mathrm{d}(P<0.001)$ and the proportion of total $\mathrm{N}$ retained in wool declined from 0.71 to $0.25(P<0.01)$. The reduction in wool growth was accompanied by a decrease in protein fractional synthesis rate (FSR) in skin $(11.6$ v. 6.3\%/d, $P<0.01)$. Muscle protein FSR, on the other hand, was markedly stimulated during cimaterol infusion $(1.45 \mathrm{v} .3 .01 \% / \mathrm{d}, P<0.001)$ as was RNA concentration $(P<0.001)$, RNA : protein $(P<0.001)$ and protein: DNA $(P<0.05)$. The estimated increase in total protein synthesis in muscle $(+24$ to $30 \mathrm{~g} / \mathrm{d})$ due to cimaterol administration was counterbalanced by reductions for skin ( -25 to $27 \mathrm{~g} / \mathrm{d})$; this may account for the lack of changes in whole-body protein synthesis following $\boldsymbol{\beta}$-agonist administration reported in other studies. Although $\mathbf{N}$ retention rapidly returned to control values following withdrawal of the drug, both wool growth and skin protein synthesis remained depressed, while muscle protein FSR declined, but not to pre-treatment values. These results suggest a persistent action of cimaterol, but whether this is a function of residue concentrations or long-term metabolic responses is not known.
\end{abstract}

p-Agonists: Cimaterol: Protein synthesis: Wool growth: Sheep

Certain $\beta$-agonists (e.g. clenbuterol, cimaterol, ractopamine) improve protein retention in both laboratory (e.g. Emery et al. 1984; Reeds et al. 1988) and commercial species (e.g. Baker et al. 1984; Beerman et al. 1986; Borohov et al. 1987; Bergen et al. 1989), with the net action directed towards increased muscle gain (e.g. Borohov et al. 1987; Williams et al. 1987; Bergen et al. 1989). Despite the consistent myotrophic response, considerable controversy still surrounds the mechanism of action of these $\beta$-agonists, with the competing claims that protein synthesis is elevated (Emery et al. 1984; Bergen et al. 1989; Maltin et al. 1989) and/or that protein degradation is depressed (Reeds et al. 1986; Borohov et al. 1987; Higgins et al. 1988; Wang \& Beerman, 1988; Weikard et al. 1992).

Several factors may contribute to this controversy, including the species and $\beta$-agonists used and possible differences between acute and chronic effects. In rodents, for example, transient stimulation of muscle protein synthesis occurs (2-4 d; Maltin et al. 1989; Hesketh et al. 1992), whereas prolonged hypertrophy appears to involve decreased degradation

* For reprints. 
(Reeds et al. 1986; Weikard et al. 1992). The situation is more confused with the commercial species because, despite muscle hypertrophy being more prolonged, reports suggest that clenbuterol reduces protein degradation in sheep (Borohov et al. 1987; Higgins et al. 1988) while ractopamine stimulates protein synthesis in pigs (Bergen et al. 1989) and possibly cattle (Smith et al. 1989). Both actions have been reported following cimaterol administration to cattle (Dawson et al. 1991).

Protein metabolism studies on larger species are complicated because the usual methodologies of protein synthesis estimation involve single measurement times, such that when comparisons are made inter-animal variability may mask the effect of treatment. This uncertainty can be reduced by intra-animal measurements, based on sequential biopsy of accessible tissues. When the biopsy approach is allied to the large dose procedure, which eliminates differences in isotopic activity between the various free amino acid pools, subtle alterations in tissue protein synthesis can be detected. This combination of techniques has been applied to study both short- and longer-term effects of cimaterol on protein synthesis in ovine muscle and skin. The latter tissue was examined because of reports that the muscle hypertrophy may be associated with a reduction in the growth rate of other tissues (Reeds et al. 1986; Williams et al. 1987; Sainz \& Wolff, 1988), including lamb wool production (Sainz \& Wolff, 1987) and mink pelt quality (Slayden et al. 1991), which may have profound effects on net S-amino acid availability for carcass gain. The mechanisms underlying reduced anabolism in non-muscle tissues following $\beta$-agonist administration have not been examined in the farm species, and such information may be important to understand the basis of the induced $\mathrm{N}$ repartitioning.

\section{MATERIALS AND METHODS}

Animals

Six Suffolk cross-bred wether lambs ( 6 months old, $35 \mathrm{~kg}$ initial live weight) were housed in individual metabolism crates and offered daily $1200 \mathrm{~g}$ lucerne (Medicago sativa) pellets (10.5 MJ metabolizable energy and $25 \mathrm{~g} \mathrm{~N} / \mathrm{kg}$ dry matter; water content $120 \mathrm{~g} / \mathrm{kg}$ ), supplied hourly in equal portions. Animals were maintained under these conditions for 3 weeks before the cimaterol infusion commenced. They were harnessed throughout the study for collection of excreta, urine by suction into $4 \mathrm{M}-\mathrm{H}_{2} \mathrm{SO}_{4}$ and faeces by bag, over $5 \mathrm{~d}$ periods. Polyvinyl chloride catheters $(0.8 \mathrm{~mm}$ i.d., $1.2 \mathrm{~mm}$ o.d.; Dural Plastics and Engineering, Dural, NSW, Australia) were inserted into each external jugular vein under local anaesthesia $3 \mathrm{~d}$ before the start of experimental studies.

\section{Design}

This involved (a) a pre-cimaterol period of $10 \mathrm{~d}$, including two $\mathrm{N}$ balance periods, measurement of wool growth (10 d), and a single determination of protein synthesis in skin and skeletal muscle biopsies; (b) a $15 \mathrm{~d}$ continuous intravenous infusion of cimaterol $(26 \mu \mathrm{g} / \mathrm{ml}$ in sterile saline $(9 \mathrm{~g} \mathrm{NaCl} / \mathrm{l})$ at $4 \mathrm{ml} / \mathrm{h}$; total $2.5 \mathrm{mg}$ cimaterol $/ \mathrm{d})$, with three $5 \mathrm{~d}$ $\mathrm{N}$ balance periods, measurement of wool growth between days 5 and 15 , and two protein synthesis determinations (day 3 and day 15); and (c) a $15 \mathrm{~d}$ post-cimaterol period with three $5 \mathrm{~d} \mathrm{~N}$ balance periods, wool growth determined between days 5 and 15 and finally a protein synthesis measurement on day 15 .

\section{Wool growth}

The fleece was clipped to a uniform $20 \mathrm{~mm}$ length at the start and finish of the experiment to determine total wool growth. To allow estimation of wool production during each period two $100 \mathrm{~mm} \times 100 \mathrm{~mm}$ patches were marked and shaved to skin level, one on each 
flank at the start of the pre-cimaterol period. After $10 \mathrm{~d}$ one patch ('treatment') was reclipped and the shavings collected. For the measurement of wool growth during the plusand post-cimaterol treatments, wool was not clipped from the 'treatment' patch during the first $5 \mathrm{~d}$ of each period to allow for the emergence time (Downes \& Sharry, 1971) of fibres from the follicle to a height above the skin that is removed by clipping. The wool was clipped, therefore, on days 5 and 15 of these periods. The patch on the alternate side was shaved at the end of the experiment and the clean wool weight compared with the total clippings. Treatment patch weights when multiplied by this ratio provided an estimate of total fleece changes during each period. The individual wool collections were weighed and then degreased with aqueous Tween $20(25 \mathrm{ml} / 1)$, followed by drying at room temperature and reweighing. Clean wool $\mathrm{N}$ was determined by Kjeldahl analysis.

\section{$N$ balance}

The lucerne pellets and collected excreta were analysed for $\mathrm{N}$ content by Kjeldahl analysis using procedures approved by the Association of Official Analytical Chemists (1980).

\section{Protein synthesis measurements}

The four serial measurements of protein synthesis followed the procedures described by Rocha et al. (1993), using $\left[1-{ }^{13} \mathrm{C}\right]$ valine, leucine and phenylalanine and [L-ring- $\left.{ }^{2} \mathrm{H}_{5}\right]$ phenylalanine (all 98-99 atoms \%; Tracer Technologies Inc., Somerville, MA, USA). The enriched amino acids were mixed with appropriate quantities of the naturally abundant form for each injection; the proportions $(\mathrm{g}: \mathrm{g})$ were valine $1 \cdot 5: 8 \cdot 5$; leucine $0 \cdot 8: 4 \cdot 2$; phenylalanine $0 \cdot 6: 2 \cdot 4$. The respective volumes of sterile water $\left(39^{\circ}\right)$ were $200 \mathrm{ml}, 250 \mathrm{ml}$ and $200 \mathrm{ml}$. The amounts injected were chosen to elevate the total body respective free amino acid concentration by approximately 10-12 times and thus establish 'flood' conditions over the period of measurement (Rocha et al. 1993). Biopsies were taken from $m$. longissimus dorsi and shaved skin from the back of each sheep before the experiment to establish the natural abundance of the appropriate protein-bound amino acids. Immediately before each injection a blood sample $(5 \mathrm{ml})$ was withdrawn to provide natural abundance of the relevant free amino acid.

The amino acids were injected intravenously over a $10-15 \mathrm{~min}$ period. Blood samples $(3 \mathrm{ml})$ for plasma free amino acid enrichment analysis were taken at $5 \mathrm{~min}$ intervals during the first $30 \mathrm{~min}$, at $10 \mathrm{~min}$ intervals between 30 and $60 \mathrm{~min}$, then at 75 and $90 \mathrm{~min}$ and immediately after the biopsies. At 90 min tissue single biopsies (approximately $200 \mathrm{mg}$ ) were removed under local anaesthesia from a small area of skin (approximately $50 \times 30 \mathrm{~mm}$ ) on the back (shaved immediately before biopsy) and $m$. longissimus dorsi and treated as described previously (Rocha et al. 1993). Care was taken to ensure that effects of previous biopsies on subsequent tissue protein synthesis were minimized. Samples were removed from areas at least $200 \mathrm{~mm}$ distant from the previous biopsy site and both sides of the backbone were used. For the final post-cimaterol measurement the animals were killed $90 \mathrm{~min}$ after the start of the large-dose injection with an overdose of pentobarbitone and then the tissue samples rapidly removed (less than $2 \mathrm{~min}$ ). The order of injections was valine, leucine, phenylalanine $\left({ }^{13} \mathrm{C}\right.$ then ${ }^{2} \mathrm{H}$ ). Concomitant studies (Rocha et al. 1993) had shown that similar rates of protein synthesis were obtained with these three amino acids but, because both leucine and phenylalanine can provoke insulin release similar to the acute actions of the $\beta$-agonists, it was decided to use these two amino acids during the period of cimaterol infusion. Use of $\left[\mathrm{L}-\mathrm{ring}-{ }^{2} \mathrm{H}_{5}\right]$ phenylalanine for the terminal measure provided a direct comparison between the chronic and post-drug effects using the same amino acid with a corresponding evaluation between the branch-chain amino acids for the pre- and acute-cimaterol treatments. 
Calculation of tissue protein synthesis rate $\left(k_{s}, \%\right.$ per $\mathrm{d}$; g protein synthesized $/ 100 \mathrm{~g}$ tissue protein per d) was as described previously (Lobley et al. 1990). Translational efficiency $\left(k_{r n a}\right.$, g protein synthesized/d per $g$ total RNA) was obtained from the division of $k_{s}$ by the $\mathrm{g}$ total RNA per $100 \mathrm{~g}$ protein.

\section{Isotope and chemical analyses}

Plasma and tissue free and protein-bound $\left[{ }^{13} \mathrm{C}\right]$ amino acids were prepared and processed for gas-liquid chromatography-mass spectrometry (GCMS) in electron impact and chemical ionization modes, and isotope-ratio mass spectrometry as described previously (Lobley et al. 1990; Rocha et al. 1993). Isotope analyses of protein-bound [L-ring${ }^{2} \mathrm{H}_{5}$ lphenylalanine was by GCMS of protein hydrolysates, as described by Calder et al. (1992).

Protein, RNA and DNA separations and measurements followed the procedures outlined by Lobley et al. (1990). Particular care was needed to ensure homogeneity of the skin samples, with frozen samples initially chopped on surfaces cooled with liquid $\mathrm{N}_{2}$ and then homogenized in $3 \mathrm{ml}$ cold water. The homogenizer rotor was then washed with water which was combined with the sample and treated with sulphosalicylic acid (final concentration $70 \mathrm{~g} / 1$ ). The subsequent stages were as described earlier (Lobley et al. 1990) except that double extraction steps were included for RNA (warm alkali) and DNA (hot perchloric acid).

\section{Statistical analyses}

Results were examined by analysis of variance for effects of period (treatment), with animals treated as blocks.

RESULTS

\section{Nitrogen retention}

All animals gained weight during the study, and no apparent adverse reactions to either treatment or biopsy were observed, except for slight redness of the eye during the first $24 \mathrm{~h}$ of cimaterol infusion. Excreta collections were also trouble-free and this is shown by the low variabilities (Table 1). $N$ digestibility was improved by 3 percentage units $(P<0.01)$ during the $\beta$-agonist administration. $N$ retentions were similar between the pre- and postdrug periods, with slightly lower values during the latter measurements, as might be expected for the larger animals maintained on a fixed intake. Cimaterol improved overall $\mathrm{N}$ retention by more then $2 \mathrm{~g} \mathrm{~N} / \mathrm{d}$ with approximately $70 \%$ of this due to reduced urinary$\mathrm{N}$ elimination (Table 1).

\section{Wool growth}

Cimaterol significantly reduced clean wool growth $(P<0.01)$ and $\mathrm{N}$ concentration $(P<$ 0.001 ; Table 2). During 5-15 d of the post-cimaterol period wool growth did not return to pre-drug values, although $\mathrm{N}$ concentration was partially restored (Table 2 ). There was no apparent effect of the repeat clipping procedure because recovery of wool from the 'control' patch on the other side matched the time-adjusted sum of the three shavings. Based on the assumption that the patch wool was typical of the general response, the contribution of fibre growth to total $\mathrm{N}$ retention (Table 1) was estimated. Before $\beta$-agonist infusion the wool represented $71 \%$ of total $\mathrm{N}$ gain, but this declined to $25 \%$ during cimaterol treatment and was only partly restored (to $40 \%$ ) during the drug-withdrawal phase (Table 2). 


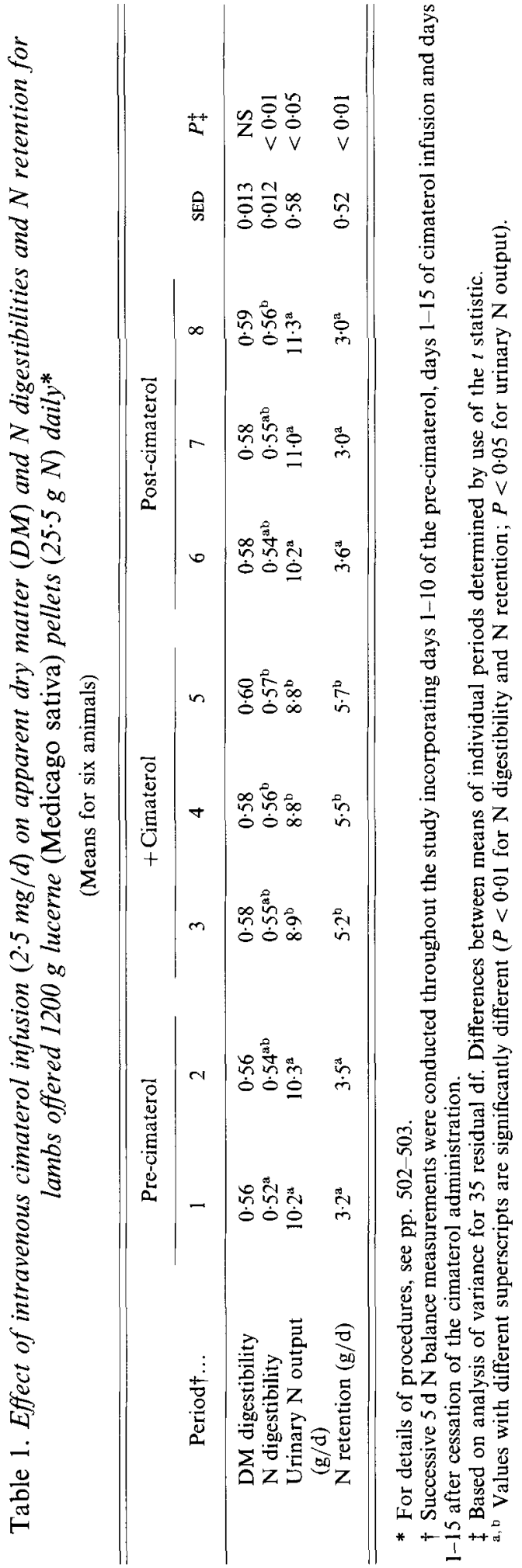


Table 2. Effect of intravenous cimaterol infusion $(2.5 \mathrm{mg} / \mathrm{d})$ on clean wool growth, wool $\mathrm{N}$ concentration and retention for lambs offered $1200 \mathrm{~g}$ lucerne (Medicago sativa) pellets daily*

(Means for six animals)

\begin{tabular}{|c|c|c|c|c|c|}
\hline & Pre-control & + Cimaterol & $\begin{array}{c}\text { Post- } \\
\text { cimaterol }\end{array}$ & SED & $P$ \\
\hline $\begin{array}{l}\text { Clean wool growth } \ddagger \\
(\mathrm{g} / \mathrm{d})\end{array}$ & $14 \cdot 7^{\mathrm{a}}$ & $10 \cdot 4^{\mathrm{b}}$ & $9 \cdot 9^{b}$ & 0.95 & $<0.01$ \\
\hline $\begin{array}{l}\text { Wool N concentration } \\
(\mathrm{g} / 100 \mathrm{~g})\end{array}$ & $14 \cdot 01^{a}$ & $12 \cdot 86^{\mathrm{b}}$ & $13 \cdot 47^{c}$ & $0 \cdot 186$ & $<0.01$ \\
\hline 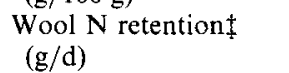 & $2 \cdot 06^{\mathrm{a}}$ & $1 \cdot 35^{\mathrm{b}}$ & $1.33^{b}$ & 0.141 & $<0.001$ \\
\hline $\begin{array}{l}\% \text { total } \mathrm{N} \text { retained } \\
\text { as wool } \mathrm{N}\end{array}$ & $70 \cdot 9^{a}$ & $25 \cdot 1^{\mathrm{b}}$ & $40 \cdot 1^{\mathrm{ab}}$ & 12.52 & $<0.01$ \\
\hline
\end{tabular}

* For details of procedures, see pp. 502-503.

a, b.c Values with different superscripts are significantly different $(P<0.01)$.

$\dagger$ By analysis of variance for 10 residual df. Differences between means assessed by use of the $t$ statistic.

$\ddagger$ Values based on weight and composition of wool from $100 \times 100 \mathrm{~mm}$ clipped patches scaled to the whole fleece.

\section{Skin metabolism}

Cimaterol treatment did not cause any significant change in either protein, RNA or DNA concentrations (Table 3), although the difficulties of preparing consistent extracts increased the variability of the determinations and may have masked real changes. There were trends for the drug to decrease DNA and also, during the acute phase $(3 \mathrm{~d})$, RNA. In consequence, protein:DNA was increased by the $\beta$-agonist, which might indicate reduced cell proliferation.

Estimates of skin protein fractional synthesis rate (FSR) for the pre-cimaterol period (mean $11.6 \% / \mathrm{d}$; Table 3) were similar to values reported both using other amino acids in large-dose procedures (Lobley et al. 1992; Rocha et al. 1993) and based on continuous infusion studies in lambs, with the plasma free amino acid isotopic activity selected as representative of the true precursor (Davis et al. 1981; Lobley et al. 1992). Protein synthesis was significantly reduced $(P<0.01)$ during both the chronic and post-cimaterol periods (Table 3). The reductions of $46 \%$ and $43 \%$, compared with pre-drug values, were similar to the 36 and $35 \%$ decreases in wool $\mathrm{N}$ retention (Table 2). Based on the assumptions that: first, the protein content of total shaved skin of $35-40 \mathrm{~kg}$ sheep is $500-570 \mathrm{~g}$ (MacRae et al. 1993); second, the skin and wool samples taken are representative of the whole; and, third, that short-term measurements of protein synthesis, made within each period, can be related to the wool $\mathrm{N}$ retention of that period, then the proportion of skin $k_{s}$ attributable to wool protein gain can be calculated to remain similar $(25-28 \%)$ before, during and after administration of the $\beta$-agonist (Table 3), despite the substantial alterations in metabolism and fibre production. Translational efficiency $\left(k_{r n a} ; \mathrm{g}\right.$ protein synthesized/d per $\mathrm{g}$ total RNA) declined during chronic cimaterol treatment $(P<0.05)$ and had not increased by the end of the $15 \mathrm{~d}$ withdrawal period (Table 3 ).

\section{Muscle metabolism}

As a result of chronic cimaterol infusion (Table 4 ) the concentration (w/w) of DNA was reduced by $28 \%(P<0.001)$ and that of protein by $15 \%(P<0.05)$. In contrast, total RNA was significantly increased $(12 \%, P<0.001)$. These effects persisted during the drug 
Table 3. Responses in protein, $R N A$ and DNA concentrations $(m g / g)$, protein synthesis $\left(\mathrm{k}_{\mathrm{s}}\right)$ and translational activity $\left(\mathrm{k}_{\mathrm{rna}}, \mathrm{g}\right.$ protein synthesized/d per $\mathrm{g}$ total $\left.R N A\right)$ in ovine skin with intravenous infusion of cimaterol $(2.5 \mathrm{mg} / \mathrm{d})^{*}$

(Means for six animals)

\begin{tabular}{|c|c|c|c|c|c|c|}
\hline & \multirow{2}{*}{$\begin{array}{l}\text { Pre- } \\
\text { cimaterol } \\
-5 \mathrm{~d}\end{array}$} & \multicolumn{2}{|c|}{ Plus-cimaterol } & \multirow{2}{*}{$\begin{array}{l}\text { Post- } \\
\text { cimaterol } \\
+15 \mathrm{~d}\end{array}$} & \multirow[b]{2}{*}{ SED } & \multirow[b]{2}{*}{$P$} \\
\hline & & $3 \mathrm{~d}$ & $15 \mathrm{~d}$ & & & \\
\hline \multicolumn{7}{|l|}{ Concentrations } \\
\hline Protein & 161 & 157 & 157 & 147 & $11 \cdot 0$ & NS $\dagger$ \\
\hline RNA & $3 \cdot 34$ & $2 \cdot 25$ & 2.94 & $2 \cdot 69$ & 0.546 & $\mathrm{NS} \dagger$ \\
\hline DNA & $2 \cdot 75$ & $1 \cdot 79$ & $2 \cdot 11$ & $1 \cdot 86$ & 0.372 & NSt \\
\hline \multicolumn{7}{|l|}{ Ratios } \\
\hline Protein:DNA & 61 & 91 & 91 & 94 & $19 \cdot 5$ & $\mathrm{NS} \dagger$ \\
\hline RNA:DNA & $1 \cdot 23$ & $1 \cdot 31$ & 1.64 & 1.48 & $0 \cdot 322$ & NSt \\
\hline RNA : protein (mg:g) & $21 \cdot 1$ & $14 \cdot 9$ & $19 \cdot 2$ & $19 \cdot 3$ & $2 \cdot 66$ & NSt \\
\hline \multicolumn{7}{|l|}{ Protein metabolism } \\
\hline$k_{s}(\%$ per $\mathrm{d})$ & $11 \cdot 6$ & $10 \cdot 9$ & $6 \cdot 3$ & $6 \cdot 6$ & 1.59 & $<0.01 t$ \\
\hline$k_{r n a}$ & $6.01^{\mathrm{ab}}$ & $7 \cdot 9^{\mathrm{a}}$ & $3 \cdot 5^{\mathrm{b}}$ & $3.7^{\mathrm{b}}$ & 0.79 & $<0.05 t$ \\
\hline $\begin{array}{l}\% \text { Skin protein synthesis } \\
\text { deposited as wool }\end{array}$ & 25 & - & 28 & 26 & $5 \cdot 5$ & $\mathrm{NS} \S$ \\
\hline
\end{tabular}

* For details of procedures, see pp. 502-504.

$\dagger$ By analysis of variance but due to technical difficulties there are missing values with, in consequence, only 11 residual $\mathrm{df}$ and with incomplete animal blocks.

$\ddagger$ By analysis of variance based on 15 residual df. Row values with unlike superscripts are significantly different $(P<0.05)$.

$\S$ By analysis of variance based on 12 residual df. Because wool growth measurements were made over 5-15 d for each period no calculations are presented for the $3 \mathrm{~d}$ plus-cimaterol time point.

I Protein synthesis measured by the large-dose procedure with $\left[1-{ }^{13} \mathrm{C}\right]$ valine, leucine and phenylalanine used successively for each of the first three measurements and $\left[\right.$ ring- $\left.{ }^{2} \mathrm{H}_{5}\right]$ phenylalanine for the post-cimaterol study.

withdrawal period (Table 4) and, as a consequence, protein:DNA, often used as an index of cell hypertrophy, increased markedly throughout the chronic and post-drug periods (by 18 and $27 \%$ respectively, $P<0.05$; Table 4$)$. Similarly, RNA:DNA, an index of cellular activity, was also elevated over the same periods ( 55 and $95 \%$ respectively, $P<0.01$ ) as was RNA:protein, a marker of the translational capacity of the tissue, by $32 \%$ and $47 \%$ respectively $(P<0.001$; Table 4$)$.

Cimaterol caused substantial increases in $k_{s}(P<0.001$; Table 4$)$. Within $3 \mathrm{~d}$ of the start of infusion $k_{s}$ was increased $90 \%$ compared with pre-drug values and this was maintained at $15 \mathrm{~d}$. Withdrawal of the $\beta$-agonist resulted in a significant reduction $(P<0.05)$ in the rate of protein synthesis but not to the pre-treatment values $(P<0 \cdot 05$; Table 4$)$. Translational efficiency also increased significantly during infusion of the drug $(P<0.01$; Table 4$)$ but returned to control values during the post-treatment phase. Based on the assumption that muscle protein gain is similar to whole-body protein accretion (from $\mathrm{N}$ retention; Table 1) and that the sheep contains $145 \mathrm{~g}$ protein $/ \mathrm{kg}$ live weight then fractional protein growth rates increased from 0.37 to $0.72 \% / \mathrm{d}$ as a result of cimaterol treatment. The incremental improvement $(0.35 \%$ per $\mathrm{d})$ was only $22 \%$ of the increase in muscle $k_{s}$ and, even allowing for preferential accretion of muscle during cimaterol trea tment, estimated protein fractional degradation in the tissue must also have increased as a result of action of the drug.

Examination of the earlier muscle and skin biopsy sites at the end of the study indicated that any damage was local, and restricted, where present, to within $5 \mathrm{~mm}$ of the wound site. 
Table 4. Responses in protein, $R N A$ and DNA concentrations $(m g / g)$, protein synthesis $\left(\mathrm{k}_{\mathrm{s}}\right)$ and translational activity $\left(\mathrm{k}_{\mathrm{rna}}, g\right.$ protein synthesized/d per $g$ total $\left.R N A\right)$ in ovine $\mathrm{m}$. longissimus dorsi with intravenous infusion of cimaterol $(2.5 \mathrm{mg} / \mathrm{d})^{*}$

(Means for six animals)

\begin{tabular}{|c|c|c|c|c|c|c|}
\hline & \multirow{2}{*}{$\begin{array}{l}\text { Pre- } \\
\text { cimaterol } \\
-5 \mathrm{~d}\end{array}$} & \multicolumn{2}{|c|}{ Plus-cimaterol } & \multirow{2}{*}{$\begin{array}{l}\text { Post- } \\
\text { cimaterol } \\
+15 \mathrm{~d}\end{array}$} & \multirow[b]{2}{*}{ SED } & \multirow[b]{2}{*}{$P \dagger$} \\
\hline & & $3 \mathrm{~d}$ & $15 \mathrm{~d}$ & & & \\
\hline \multicolumn{7}{|l|}{ Concentrations } \\
\hline Protein & $157^{\mathrm{a}}$ & $144^{\mathrm{ab}}$ & $134^{\mathrm{b}}$ & $138^{\mathrm{b}}$ & $7 \cdot 3$ & $<0.05$ \\
\hline RNA & $0.78^{a}$ & $0 \cdot 76^{\mathrm{a}}$ & $0.87^{\mathrm{b}}$ & $1.01^{\mathrm{c}}$ & 0.042 & $<0.001$ \\
\hline DNA & $0.54^{\mathrm{a}}$ & $0 \cdot 50^{\mathrm{a}}$ & $0 \cdot 39^{\mathrm{b}}$ & $0 \cdot 36^{\mathrm{b}}$ & 0.024 & $<0.001$ \\
\hline \multicolumn{7}{|l|}{ Ratios } \\
\hline Protein:DNA & $294^{\mathrm{ab}}$ & $286^{\mathrm{a}}$ & $345^{\mathrm{bc}}$ & $382^{\mathrm{c}}$ & $28 \cdot 5$ & $<0.05$ \\
\hline RNA: DNA & $1 \cdot 46^{\mathrm{a}}$ & $1.52^{\mathrm{a}}$ & $2 \cdot 23^{b}$ & $2 \cdot 79^{\mathrm{C}}$ & 0.139 & $<0.01$ \\
\hline RNA: protein (mg:g) & $4.96^{\mathrm{a}}$ & $5 \cdot 30^{\mathrm{a}}$ & $6 \cdot 49^{b}$ & $7 \cdot 30^{c}$ & $0 \cdot 362$ & $<0.001$ \\
\hline \multicolumn{7}{|l|}{ Protein metabolism } \\
\hline$k_{s}(\%$ per $\mathrm{d})$ & $1 \cdot 45^{a}$ & $2 \cdot 76^{\text {be }}$ & $3 \cdot 01^{\mathrm{b}}$ & $2 \cdot 20^{\mathrm{c}}$ & $0 \cdot 332$ & $<0-001$ \\
\hline$k_{\mathrm{rna}}$ & $2 \cdot 89^{a}$ & $5 \cdot 23^{\mathrm{b}}$ & $4.63^{b}$ & $2 \cdot 97^{\mathrm{a}}$ & 0.704 & $<0.01$ \\
\hline$k_{g} \S$ & $0.43^{\mathrm{a}}$ & $0 \cdot 66^{\mathrm{b}}$ & $0.72^{\mathrm{b}}$ & $0.37^{\mathrm{a}}$ & 0.057 & $<0.001$ \\
\hline
\end{tabular}

* For details of procedures, see pp. 502-504.

$\dagger$ By analysis of variance based on 15 residual df. Row values with unlike superscripts are significantly different $(P<0.05)$.

$\S$ Whole body fractional rates of $\mathrm{N}$ retention; based on $\mathrm{N}$ balance data (Table 1) and assumed $\mathrm{N}$ content for sheep of $23 \mathrm{~g} \mathrm{~N} / \mathrm{kg}$ liveweight.

I Protein synthesis measured by the large-dose procedure with $\left[1-{ }^{13} \mathrm{C}\right]$ valine, leucine and phenylalanine used successively for each of the first three measurements and $\left[\right.$ ring- ${ }^{2} \mathrm{H}_{5}$ ]phenylalanine for the post-cimaterol study.

Effects of local reactions on the other biopsy sites were considered, therefore, to be minimal, but systemic effects could not be eliminated although the general health and well-being of the animals makes any deleterious responses unlikely, especially as measurements were made at intervals of between 7 and $15 \mathrm{~d}$.

\section{DISCUSSION}

The improvement in $\mathrm{N}$ retention during the period of cimaterol infusion confirms the many observations that certain $\beta$-agonists produce substantial and prolonged improvements in protein gain for farm species (e.g. Baker et al. 1984; Beerman et al. 1987; Borohov et al. 1987; MacRae et al. 1988; Bergen et al. 1989; Dawson et al. 1991). Because the animals were maintained on a fixed intake throughout the study, and $\mathrm{N}$ digestibility was only slightly enhanced by cimaterol, a large improvement in the net efficiency of utilization of absorbed amino acids almost certainly occurred. Similar improvements in total protein gain in milk-fed calves treated with clenbuterol included a repartitioning between lean tissues, such that the extra accretion in muscle exceeded that for the whole animal, with the rates of gain in other tissues reduced (Williams et al. 1987). In the current study part of such repartitioning included depression in wool growth and, presumably, the net production of cyst(e)ine-rich keratins. For ruminants supplied with forage diets rumen microbial protein provides the bulk of absorbed amino acids and many studies have indicated that methionine is often first limiting under such conditions (e.g. Nimrick et al. 1970; Storm \& Ørskov, 1984). One of the fates of methionine is donation of $\mathrm{S}$ to cysteine synthesis and, if the demands for fibre production are considerable, then this may limit the amount of 
methionine available for protein gain in other tissues. Indeed, provision of extra methionine to sheep often increases wool growth (Reis et al. 1990).

One underlying mechanism in the repartitioning of protein to muscle appears to involve a decrease in skin synthesis. The current study did not distinguish between skin constitutive protein and fibre synthesis but, because wool protein accretion represents a small proportion of total integument protein metabolism during both control and treatment phases, then, even allowing for the processing losses of the prokeratins, a general reduction of skin protein synthesis appears more probable. The reduction may be due to reduced availability of essential amino acids, particularly methionine and cysteine, diverted to improved muscle protein gain. If this resulted in lowered production of the high-S protein in the fibre matrix it would also account for the lowered $\mathrm{N}$ content of the fibre, because the matrix proteins determine the variation in fibre $\mathrm{N}$ contents (Gillespie, 1983). The decrease in skin protein synthesis associated with cimaterol treatment may also have resulted from reduced integument cell proliferation rates, which have been reported to decline in response to adrenaline treatment (Rao et al. 1971; Aoyagi et al. 1980), possibly acting via a negative feedback mechanism (Cameron, 1971). This may be a general feature of sympathomimetics, including cimaterol, and is supported by the trend towards reduced DNA concentrations in the current study.

The mechanisms underlying the myotrophic response to $\beta$-agonists are still the subject of controversy. Data are available supporting increases in protein synthesis (Emery et al. 1984; Bergen et al. 1989; Maltin et al. 1989; Dawson et al. 1991; Hesketh et al. 1992) and decreases in degradation (Reeds et al. 1986; Borohov et al. 1987; Maltin et al. 1987; Dawson et al. 1991; Weikard et al. 1992). Furthermore, ractopamine has been shown to increase the abundance of mRNA for muscle proteins in both pigs (Helferich et al. 1990) and steers (Smith et al. 1989), indicative of a pre-translational potential for stimulation of protein synthesis. In contrast, both clenbuterol and cimaterol when given to lambs have reduced the activity of certain proteolytic enzymes, especially the calpains (Higgins et al. 1988; Wang \& Beerman, 1988; Kretchmar et al. 1989), responsible for loosening the myofibrillar network, with the implication that protein degradation is inhibited. The current results do not support this latter concept, at least under the experimental conditions employed, since the substantial changes in protein synthesis observed more than exceeded the calculated response in muscle growth. This would imply a probable increase in proteolysis, similar to the situation observed in many nutritional studies, where synthesis and degradation alter in the same direction, but to different extents (Millward et al. 1976; Harris et al. 1992). Changes in enzyme activity do not necessarily presume that metabolic responses follow since both substrate availability (possibly linked to compartmentalization of proteases) and sensitivity may also need to be altered. Why such consistent changes in apparent proteolytic activity occur following $\beta$-agonist treatment remains a mystery, but may be linked to a required remodelling of the myofibrillar structure. Indeed, while catheptic activities can be reduced by cimaterol in vitro, net anabolism is not observed (Bechet et al. 1990).

The increased muscle protein synthesis provoked by cimaterol had associated changes in cellular RNA, and the marked rise in both absolute concentration and RNA:protein are supportive of increases in the synthetic capacity of the tissue. These findings are not in agreement with those of Beerman et al. (1987), where no change in either variable was observed after 7 or 12 weeks of cimaterol administration to lambs. Beerman et al. (1987) did, however, report a lowered DNA concentration and elevated RNA:DNA, findings confirmed in the current study. The reason for the lowered DNA is unclear, but may involve reduced satellite cell numbers, particularly if differentiation, followed by incorporation into the myofibre, forms part of the anabolic process. In the present study 
the proportional chronic increases observed in synthesis exceeded those in RNA, such that translational efficiency was also elevated. While $k_{r n a}$ measurements are rather simplistic, both in practical and theoretical terms, they are often associated with stimulatory events, such as the transitions in the fed-fast cycle (Millward et al. 1976; Garlick et al. 1983). In muscle (and other tissues) of fattening ruminants translational activity is usually much lower than for the preruminant and young nonruminant and, therefore, has the capacity to respond to appropriate stimuli (Lobley, 1993).

There is evidence from cell culture studies that certain $\beta$-agonists can stimulate muscle protein synthesis directly (Young et al. 1987; Anderson et al. 1990), probably through actions at a $\beta_{2}$-receptor (Sillence et al. 1991), although interactions with humoral factors cannot be excluded at present. The fact that $\beta$-agonists have been shown to work in adrenalectomized, hypophysectomized and gonadectomized animals appears to eliminate many of the major systemic hormones (see Yang \& McElligott, 1989). A direct action on muscle would be expected to lead to rapid reversal of effects and the restoration of wholebody total $\mathrm{N}$ retention to pre-drug values (McRae et al. 1988; Hovell et al. 1989; present investigation) has tended to support this view. The current results cast doubt on this simplistic interpretation as muscle protein synthesis is maintained above control rates while wool growth is still markedly depressed during the 5 to $15 \mathrm{~d}$ period after withdrawal of cimaterol. One possible explanation for the persistent effect on muscle may involve neural interactions. It has been observed that clenbuterol is effective in reducing the atrophy associated with nerve damage (Maltin et al. 1987) and suggestions have been made that nerve-derived growth factors (NDGF) may play an important role in myotrophic growth (Davis et al. 1985). Recovery from nerve damage or metabolic modifications can be lengthy and stimulated production of NDGF or associated regulatory proteins may continue for some time following termination of drug treatment. The residual effect of cimaterol on wool growth may be linked to possible lowered rates of cell division in the follicle, resulting in reduced follicle size. Evidence from nutritional studies suggests that, in circumstances where follicle size is reduced, periods as long as 3 to 5 weeks are required before size and, therefore, productivity are restored (Hynd, 1982). Alternative explanations may involve either very low concentrations of cimaterol being required to maintain metabolic changes after the initial responsive dose or the drug remaining within tissues at active doses. There is some evidence for accumulation of $\beta$-agonists in the eye of calves but, in general, residue levels in most tissues are reduced rapidly to low concentrations (Meyer \& Rink, 1991).

Measurements of whole-body amino acid flux, corrected to total protein synthesis, have often shown little or no change in response to $\beta$-agonists (Borohov et al. 1987; MacRae et al. 1988) and the current findings offer an explanation. Based on the assumptions that the skin and muscle samples taken are representative, that total protein values in skin and muscle are $500 \mathrm{~g}$ and $1900 \mathrm{~g}$ respectively for sheep of $35 \mathrm{~kg}$ (MacRae et al. 1993) and that the responses observed to cimaterol are typical of $\beta$-agonists, then the increased synthesis in muscle $(+24$ to $30 \mathrm{~g} / \mathrm{d})$ during short- and long-term administration of cimaterol is counterbalanced by reduced integument activity ( -25 to $27 \mathrm{~g} / \mathrm{d}$ ).

This study again demonstrates the considerable protein repartitioning effect of $\beta$ agonists towards muscle and reveals that the effects are aided by reduced gain, through lowered protein synthesis, in the integument. Whether similar metabolic effects occur in other, non-muscle tissues that show decreased rates of protein accretion remains to be investigated. The disturbance of the normal distribution of lean protein mass induced by $\beta$-agonists provides an important approach to understanding the mechanisms which regulate body composition and which may be manipulated either for animal production or for reversal of protein wasting ailments. 
J.E.N. and H.J.G.R. are recipients of post-graduate studentships from the Ministry of Agriculture, Fisheries and Food and The European Community respectively. Many of the costs for the study were borne by a grant from the Scottish Office Agriculture and Fisheries Department as part of the core budget to the Rowett Research Institute.

\section{REFERENCES}

Anderson, P. T., Helferich, W. G., Parkhill, L. C., Merkel, R. A. \& Bergan, W. G. (1990). Ractopamine increases total and myofibrillar protein synthesis in cultured rat myotubes. Journal of Nutrition 120, 1677-1683.

Aoyagi, T., Adachi, K., Halprin, K. M. \& Levine, V. (1980). The effects of epidermal growth factor on the cyclic nucleotide system in pig epidermis. Journal of Investigatory Dermatology 74, 238-241.

Association of Official Analytical Chemists (1980). Official Methods of Analysis, 12th ed., Washington, DC: Association of Official Analytical Chemists.

Baker, P. K., Dalrymple, R. H., Ingle, D. L. \& Ricks, C. A. (1984). Use of a $\beta$-adrenergic agonist to alter muscle and fat deposition in lambs. Journal of Animal Science 59, 1256-1261.

Bechet. D. M., Listrat, A., Delval, C., Ferrara, H. \& Quirke, J. F. (1990). Cimaterol reduces cathepsin activities but has no anabolic effect in cultured myotubes. American Journal of Physiology 259, E822-E827.

Beermann, D. H., Butler, W. R., Hogue, D. E., Fishell, V. K., Dalrymple, R. H., Ricks, C. A. \& Scanes, C. G. (1987). Cimaterol induced muscle hypertrophy and alternate endocrine status in lambs. Journal of Animal Science 65, 1514-1524.

Beerman, D. H., Hogue, D. E., Fishell, V. K., Dalrymple, R. H. \& Ricks, C. A. (1986). Effects of cimaterol and fish meal on performance, carcass characteristics and skeletal muscle growth in lambs. Journal of Animal Science 62, $370-380$

Bergen, W. G., Johnson, S. M., Sjaerlund, D. M., Babiker, A. S., Ames, N. K., Merkel, R. A. \& Anderson, D. A. (1989). Muscle protein metabolism in finishing pigs fed ractopamine. Journal of Animal Science 67, 2255-2262.

Bohorov, O., Buttery, P. J., Correia, J. H. R. D. \& Soar, J. B. (1987). The effect of the $\beta-2$ adrenergic agonist clenbuterol or implantation with oestrogen plus trenbolone acetate in wether lambs. British Journal of Nutrition 57, 99-107.

Calder, A. G., Anderson, S. E., Grant, I., McNurlan, M. A. \& Garlick, P. J. (1992). The determination of low d - $^{-}$ phenylalanine enrichment $(0.002-0.09$ atom percent excess), after conversion to phenylethylamine, in relation to protein turnover studies by gas chromatography/electron ionization mass spectrometry. Rapid Communications in Mass Spectrometry 6, 421-424.

Cameron, I. L. (1971). Cell proliferation and renewal in the mammalian body. In Cellular and Molecular Renewal in the Mammalian Body, pp. 48-85 [I. L. Cameron and J. D. Thrasher, editors]. New York: Academic Press.

Davis, H. L., Heinicke, E. A., Cook, R. A. \& Kiernan, J. A. (1985). Partial purification from mammalian peripheral nerve of a trophic factor that ameliorates atrophy of denervated muscle. Experimental Neurology 89 , 159-171.

Davis, S. R., Barry, T. N. \& Hughson, G. A. (1981). Protein synthesis in tissues of growing lambs. British Journal of Nutrition 46, 409-419.

Dawson, J. M., Buttery, P. J., Lammimamn, M. J., Soar, J. B., Essex, C. P., Gill, M. \& Beever, D. E. (1991). Nutritional and endocrinological manipulation of lean deposition in forage-fed steers. British Journal of Nutrition 66, 171-185.

Downes, A. M. \& Sharry, L. F. (1971). Measurement of wool growth and its response to nutritional changes. Australian Journal of Biological Sciences 24, 117-130.

Emery, P. W., Rothwell, N. J., Stock, J. J. \& Winter, P. D. (1984). Chronic effects of $\beta_{2}$ adrenergic agonists on body composition and protein synthesis in the rat. Bioscience Reports 4, 83-91.

Garlick, P. J., Ferns, M. \& Preedy, V. R. (1983). The effect of insulin infusion and food intake on muscle protein synthesis in postabsorptive rats. Biochemical Journal 210, 669-676.

Gillespie, J. M. (1983). The structural proteins of hair: isolation, characterization, and regulation of biosynthesis. In Biochemistry and Physiology of the Skin, pp. 475-510 [L. A. Goldsmith, editor]. New York: Oxford University Press.

Harris, P. M., Skene, P. A., Buchan, V., Milne, E., Calder, A. G., Anderson, S. E., Connell, A. \& Lobley, G. E. (1992). Effect of food intake on hind-limb and whole body protein metabolism in growing lambs: chronic studies based on arterio-venous techniques. British Journal of Nutrition 68, 389-407.

Helferich, W. G., Jump, D. B., Anderson, D. B., Skjaerlund, D. M., Merkel, R. A. \& Bergan, W. G. (1990). Skeletal muscle $\alpha$-actin synthesis is increased pretranslationally in pigs fed phenethanolamine ractopamine. Endocrinology 126, 3096-3100.

Hesketh, J. E., Campbell, G. P., Lobley, G. E., Maltin, C. A., Acamovic, F. \& Palmer, R. M. (1992). Stimulation of actin and myosin synthesis in rat gastrocnemius muscle by clenbuterol; evidence for translation control. Comparative Biochemistry and Physiology 102, 23-27.

Higgins, J. A., Lasslett, Y. V., Bardsley, R. G. \& Buttery, P. J. (1988). The relation between dietary restriction or clenbuterol (a selective $\beta_{2}$ agonist) treatment on muscle growth and calpain proteinase $(E C 3.4 .22 .17$.$) and$ calpastatin activities in lambs. British Journal of Nutrition 60, 645-652. 
Hovell, F. D. DeB., Kyle, D. J., Reeds, P. J. \& Beermann, D. H. (1989). The effect of clenbuterol and cimaterol on the endogenous nitrogen loss in sheep. Nutrition Reports International 39, 1177-1182.

Hynd, P. I. (1982). Wool growth efficiency: a study of the effects of liveweight status and diet on wool growth. $\mathrm{PhD}$ Thesis, University of Adelaide, Australia.

Kretchmar, D. H., Hathaway, M. R., Epley, J. \& Dayton, W. R. (1989). In vivo effect of a $\beta$ adrenergic agonist on activity of calcium-dependent proteinases, their specific inhibitor, and cathepsins $\mathrm{B}$ and $\mathrm{H}$ in skeletal muscle. Archives of Biochemistry and Biophysics 275, 228-235.

Lobley, G. E. (1993). Species comparisons of tissue protein metabolism: effects of age and hormonal action. Journal of Nutrition 123, 337-343.

Lobley, G. E., Connell, A., Milne, E., Buchan, V., Calder, A. G., Anderson, S. E. \& Vint, H. (1990). Muscle protein synthesis in response to testosterone administration in wether lambs. British Journal of Nutrition $\mathbf{6 4}$, $691-704$.

Lobley, G. E., Harris, P. M., Skene, P. A., Brown, D., Milne, E., Calder, A. G., Anderson, S. E., Garlick, P. J., Nevison, I. \& Connell, A. (1992). Responses in tissue protein synthesis to sub- and supra-maintenance intake in growing sheep; comparison of large-dose, and continuous-infusion technique. British Journal of Nutrition 68 , 373-388.

MacRae, J. C., Skene, P. A., Connell, A., Buchan, V. \& Lobley, G. E. (1988). The action of the $\beta$-agonist clenbuterol on protein and energy metabolism in fattening wether lambs. British Journal of Nutrition $\mathbf{5 9}$, $457-465$.

MacRae, J. C., Walker, A., Brown, D. \& Lobley, G. E. (1993). Accretion of total protein and individual amino acids by organs and tissues of growing lambs and the ability of nitrogen balance techniques to quantitate protein retention. Animal Production 57, 237-245.

Maltin, C. A., Hay, S. M., Delday, M. I., Lobley, G. E. \& Reeds, P. J. (1989). The action of the $\beta$-agonist clenbuterol on protein metabolism in innervated and denervated phasic muscles. Biochemical Journal 261, 965-971.

Maltin, C. A., Hay, S. M., Delday, M. I., Smith, F. G., Lobley, G. E. \& Reeds, P. J. (1987). Clenbuterol, a beta agonist, induces growth in innervated and denervated rat soleus muscle via apparently different mechanisms. Bioscience Reports 7, 525-532.

Meyer, H. H. D. \& Rinke, L. M. (1991). The pharmacokinetics and residues of clenbuterol in veal calves. Journal of Animal Science 69, 4538-4544.

Millward, D. J., Garlick, P. J., Nnanyelugo, D. O. \& Waterlow, J. C. (1976). The relative importance of muscle protein synthesis and breakdown in the regulation of muscle mass. Biochemical Journal 156, 185.

Nimrick, K., Hatfield, E. E., Kaminski, J. \& Owens, F. N. (1970). Qualitative assessment of supplemental amino acid need for growing lambs fed urea as the sole nitrogen source. Journal of Nutrition 100, 1293-1300.

Rao, G. S., Del Monte, M. \& Nadler, H. L. (1971). Adenyl cyclase activity in cultivated human skin fibroblasts. Nature New Biology 232, 253-255.

Reeds, P. J., Hay, S. M., Dorward, P. M. \& Palmer, R. M. (1986). Stimulation of muscle growth by clenbuterol: lack of effect on muscle protein biosynthesis. British Journal of Nutrition 56, 249-258.

Reeds, P. J., Hay, S. M., Dorward, P. M. \& Palmer, R. M. (1988). The effect of $\beta$-agonists and antagonists on muscle growth and body composition in young rats (Rattus sp.). Comparative Biochemistry and Physiology 89C, 337-341.

Reis, P. J., Tunks, D. A. \& Munro, S. G. (1990). Effects of the infusion of amino acids into the abomasum of sheep, with emphasis on the relative value of methionine, cysteine and homocysteine for wool growth. Journal of Agricultural Science (Camb) 114, 59.

Rocha, H. G., Nash, J., Connell, A. \& Lobley, G. E. (1993). Protein synthesis in ovine muscle and skin: sequential measurements with three different amino acids based on the large dose procedure. Comparative Biochemistry and Physiology 105, 301-307.

Sainz, R. D. \& Wolff, J. E. (1987). Mechanisms of action of repartitioning agents: quantitative and dynamic evaluation of alternative hypotheses. Proceedings of the 2nd International Symposium on the Nutrition of Herbivores, pp. 153-154. Brisbane: Australian Society of Animal Production.

Sainz, R. D. \& Wolff, J. E. (1988). Effects of the $\beta$-agonist, cimaterol, on growth, body composition and energy expenditure in rats. British Journal of Nutrition $60,85-90$.

Sillence, M. N., Matthews, M. L., Spiers, W. G., Pegg, G. G. \& Lindsay, D. B. (1991). Effects of clenbuterol, ICI 118551 and sotatol on the growth of cardiac and skeletal muscle and on $\beta_{2}$-adrenoceptor density in female rats. Naunyn-Schmiedeberg's Archivs für Pharmacologia 344, 449-453.

Slayden, O., Oldfield, J. E. \& Stormshak, F. (1991). Growth and furring of mink (Mustela vison) given diets containing the $\beta$-adrenergic agonist, cimaterol. Animal Production 52, 377-381.

Smith, S. B., Garcia, D. K. \& Anderson, D. B. (1989). Elevation of specific mRNA in longissimus muscle of steers fed ractopamine. Journal of Animal Science 67, 3495-3502.

Storm, E. \& Ørskov, E. R. (1984). The nutritive value of rumen microorganisms in ruminants. 4 . The limiting amino acids of microbial protein in growing sheep determined by a new approach. British Journal of Nutrition $52,613-622$.

Wang, S. Y. \& Beermann, D. H. (1988). Reduced calcium dependent proteinase activity in cimaterol induced muscle hypertrophy in lambs. Journal of Animal Science 66, 2545-2550. 
Weikard, R., Reichel, K. \& Rehfeldt, C. (1992). Changes in protein synthesis, protein degradation and nucleic acid content in response to the beta-adrenergic agonist, clenbuterol, in muscles of rats. Archiv für Tierzucht Dummerstorf 35, 421-429.

Williams, P. E. V., Pagliani, L., Innes, G. M., Pennie, K., Harris, C. I. \& Garthwaite, P. (1987). Effect of a $\beta$ agonist (clenbuterol) on growth, carcass composition, protein and energy metabolism of veal calves. British Journal of Nutrition 57, 417-428.

Yang, Y. T. and McElligott, M. A. (1989). Multiple actions of $\beta$-adrenergic agonists on skeletal muscle and adipose tissue. Biochemical Journal 261, 1-10.

Young, R. B., McGee, C. G., Moriarty, D. M., Richter, H. E., Campbell, M. R., Maupin, J. A. \& Hudson, J. R. (1987). Protein metabolism in chicken muscle cell cultures treated with cimaterol. Federation Proceedings 46 , 1020. 